RECENZJE : PRZEGLĄDY : SPRAWOZDANIA

$$
\text { REVIEWS : NOTICES : REPORTS }
$$




\title{
O ŚWIECIE ZANURZONYM W MODALNOŚCI
}

\author{
GRAŻYNA SZWAT-GYŁYBOWA \\ Institute of Slavic Studies PAS
}

\begin{abstract}
ON A WORLD IMMERSED IN MODALITY. A review of: Siedlecka, Sylwia. Złote piachy [Golden Dusts]. Wołowiec: Czarne, 2019. The author presents an overview of the separate texts in Siedlecka's book on post-communist Bulgaria. While stating that the texts belong to nonfiction, the review questions the critical definitions of those texts as reports, suggesting further discussions on their genre.

Keywords: Sylwia Siedlecka, post-communism, Bulgaria, Bulgarian culture, nonfiction
\end{abstract}

Pisarstwo naukowe i beletrystykę Sylwii Siedleckiej śledzę od dawna. Spodziewałam się, że w obrębie uprawianych przez nią stylów i gatunków mogą się pojawić nowe brawurowe realizacje interesujących pomysłów. Z prawdziwym jednak zaskoczeniem i podziwem dla kreatywności Autorki przyjęłam najnowszy zbiór tekstów o Bułgarii - Złote piachy (2019), opublikowany przez Wydawnictwo Czarne w serii SULINA.

Powstawaniu tej książki przyglądałam się na różnych etapach i od pierwszej lektury towarzyszyło mi przekonanie, że jest to dzieło oryginalne i społecznie pożyteczne. Jego powstanie poprzedzały wieloletnie studia bułgarystyczne Autorki, skutkujące jej znakomitym przygotowaniem merytorycznym także w zakresie badań nad historią bułgarskich imaginariów zbiorowych i narodowych mitów. Widzę Sylwię ze skalpelem w ręku, kiedy w skupieniu i z chirurgiczną precyzją (ukrytą za gestami roztargnienia i niefrasobliwości) oddziela to, co należy do grupy w miarę zobiektywizowanych faktów historycznych od tego, co jest inkorporowanym w procesie socjalizacji fantazmatem, który chce uchodzić za jedyna prawdę, a obie razem od żywej, pulsującej krwią tkanki życia.

Drugą obok naukowej ścieżką rozwoju, która doprowadziła Siedlecką do pomysłu napisania Złotych piachów, były szlify prozatorskie. Już w debiutanckim tomiku Szczeniaki (2010) Autorka ujawniła wyobraźnię artystyczną, która uwodzi czytelnika siłą jednania sprzeczności, gdzie okrucieństwo chłodnego spojrzenia spotyka się z liryzmem, tragizm z podszytą humorem groteską. To ze spotkania tych dwu umiejętności powstał omawiany tu zbiór tekstów, który skuteczniej niż pisane przez nas - humanistów akademickie 
podręczniki służyć będzie upowszechnieniu wiedzy na temat kultury współczesnej Bułgarii. Przy okazji skłonić też powinien do pogłębionej refleksji wszystkich tych, którym nieobojętna jest kondycja świata. Uważne oko potrafi bowiem uchwycić typologiczne powinowactwa kultury małego kraju, jakim jest Bułgaria, z innymi semiosferami, a wraz z tym prostą prawdę, iż w książce mowa jest o zjawiskach (estetycznych, etycznych, politycznych, religijnych) w sensie typologicznym spowinowaconych ze zjawiskami niekiedy trudniejszymi do uchwycenia na gruncie dużych kultur. Obrana przez Siedlecką z pozoru przystępna i trzymająca w napięciu forma przekazu pozwoliła złożoną wiedzę akademicką przybliżyć odbiorcom otwartym na niepowierzchowny przekaz, intelektualnie czujnym, gotowym na odrzucenie przesądów, na niespodziewane przemieszczenia w świecie kreowanych przez Autorkę metafor. W książce mowa jest bowiem nie tylko o Bułgarii, ale też o całym NASZYM rozpadającym się świecie, gdzie wszystko co trwałe rozpada się w powietrzu.

W licznych reakcjach krytyki literackiej na książkę Złote piachy przewija się słowo reportaż; mam jednak wątpliwość co do tak jednowymiarowego zaklasyfikowania zróżnicowanych tekstów Siedleckiej. Nie budzi wątpliwości, że mieszczą się one w pojemnej kategorii literatura faktu. Ale czy są to reportaże? Może eseje? Opisy podróży? Notatki z rozmów? Raporty ze śledztwa? Wywiady? Gawędy? Fabularyzowane historie?

Książka zawiera 9 tekstów, z których każdy podejmuje odrębny temat, o wysokiej randze w zbiorowym imaginarium współczesnych Bułgarów. Pierwszy z esejów Myślcie o mnie jak o ogniu poświęcony jest burzliwemu (osobistemu i politycznemu) życiu oraz niewyjaśnionym okolicznościom śmierci Ludmiły Żiwkowej - okultystki, minister kultury w Bułgarskiej Republice Ludowej, córki Todora Żiwkowa - przez dziesięciolecia I sekretarza Bułgarskiej Partii Komunistycznej, stojącego na czele państwa do 1989 roku. Ta kontrowersyjna (także w szeregach byłego establishmentu), boleśnie tragiczna a zarazem tragikomiczna postać, reformatorka kultury socjalistycznej w duchu ezoterycznej mistyki, czerwona księżniczka głosząca długie bełkotliwe przemówienia, łaskawa mecenaska sztuki, twórczyni nieformalnego elitarnego salonu, ofiara walki między politycznymi koteriami, w pewien sposób ogniskuje w sobie cechy niemałej części konformistycznie nastawionej inteligencji bułgarskiej doby BRL-u, która swoim dążeniu do światopoglądowego synkretyzmu doświadczyła triumfu zdobywców i klęski pokonanych.

Reportaż Buzłudża z pozoru ma za bohatera słynnego w okresie komunizmu bułgarskiego architekta Gerogiego Stoiłowa; przez pryzmat losów wzniesionego na górskim szczycie przy jego udziale pomnika komunizmu narratorka w sposób syntetyczny, ale i metaforyczny przedstawia narodziny, rozkwit i krach tej ideologii w Bułgarii. Nie można być pewnym, czy rzeczywisty, czy domniemany. Trzecia część książki Ahmet, czyli Asparuch poświęcona jest historii przymusowej zmiany nazwisk, jaką komunistyczne państwo 
przeprowadziło na przełomie 1984 i 1985 roku u liczącej ponad osiemset tysięcy mniejszości tureckiej. Tej akcji bułgaryzacji, w którą zaprzęgnięta została armia oraz administracja państwowa na wszystkich jej szczeblach (z zarządami cmentarzy włącznie) towarzyszyła przemoc. Na przykładzie losów jednej rodziny Siedlecka rekonstruuje przebieg tego tzw. procesu odrodzeniowego (ta nazwa stała się w Bułgarii eufemizmem kamuflującym bezwzględne okrucieństwo akcji), której towarzyszyły represje, ale też desperackie akty protestu, indywidualne i zbiorowe, udane lub nie samobójstwa... Przywrócenie nazwisk muzułmańskich po 1989 roku, choć godne pochwały, nie przyniosło zadośćuczynienia. Siedlecka pozostawia więc czytelnika z pytaniami, pozbawionymi odpowiedzi.

Kolejny reportaż pt. Wanga stawia w centrum uwagi postać zmarłej w 1996 roku niewidomej prorokini (ponoć najbardziej znanej w świecie Bułgarki) po to, by przez pryzmat jej - także pośmiertnych - losów przybliżyć czytelnikowi świat duchowości popularnej wśród Bułgarów, rozpiętej między prawosławiem a ezoteryką, a zarazem niewolnej od swoistej korespondencji z siłami dnia, i to jakby niezależnie od ich umiejscowienia w spectrum politycznym. Tekst ten koresponduje z pierwszym esejem o Ludmile Żiwkowej, dopełniając obraz okultystycznych ciągotek bułgarskich elit politycznych XX wieku w każdym z ustrojów, w których przyszło Wandze żyć.

Z kolei Piosenka ludowa o transformacji to przewrotny tytuł dla podjętej przez Siedlecką próby rekonstrukcji (i metaforyzacji) toczącego się od ponad dwóch dekad procesu bułgarskiej transformacji ustrojowej, którego potoczną nazwą stało po przełomie 1989 roku tzw. przejście (bułg. npexod). Piosenki z niskiego nurtu czałgi (pogardzanego przez elity, ale powszechnego na gruncie kultury popularnej), mumia Dimitrowa i historia jego mauzoleum, mafijne porachunki, mądrości Wangi i Kaszpirowskiego, refleksje przypadkowych rozmówców i uczonych, tworzą rozedrgany, kalejdoskopowy obraz bułgarskiej dekompozycji systemu komunistycznego i towarzyszących temu nieklarownych procesów wprowadzania gospodarki wolnorynkowej i demokracji. W tych warunkach dominantą w przestrzeni publicznej staje się destrukcja, powolna, trudna i niespektakularna, czego metaforą u Siedleckiej są losy z trudem wysadzonego w powietrze mauzoleum Dimitrowa.

Sabina to tekst poświęcony domniemanej agenturalnej przeszłości wybitnej bułgarskiej emigracyjnej intelektualistki Julii Kristevej. Skonstruowany został w poetyce kolażu. Komentarz odautorski jest w tym wypadku skromny i jakby oczyszczony z emocji. Na kolaż składają się fragmenty raportów służb, wypowiedzi i zeznania samej Kristevej, komentarze bułgarskich intelektualistów. Tworzą one obraz rzeczywistości jakby zdeterminowanej przez zaprogramowaną nierozróżnialność kłamstwa i prawdy, co u Siedleckiej staje się znakiem epoki wewnętrznie niepojednanej i pojednania nieszukającej. 
$Z$ jednego gardła dwa głosy to opowieść o spotkaniu folkloryzmu doby późnego socjalizmu z wolnorynkowym konsumpcjonizmem. Jej osnową jest historia odkrytego w l. 70. i spopularyzowanego na Zachodzie kobiecego chóru Misterium Głosów Bułgarskich. Siedlecka wydobywa tu pewien paradoks, wynikający z faktu, iż ta programowo nieautentyczna, odległa od bułgarskiej tradycji wokalnej formacja od ponad czterdziestu lat pozostaje atrakcyjną ofertą eksportową, która może być odnawiana dzięki prawdziwym talentom wokalnym i bułgarskim praktykom kulturowym. Ten rozdział książki to swoisty kontrapunkt w kompozycji, będący nietypowym hołdem złożonym bułgarskiemu folklorowi muzycznemu.

Kolejny reportaż o zagadkowym tytule Bałkanski dotyczy bułgarskiego cyrku, przed 1989 rokiem cieszącego się renomą także poza granicami kraju. Ta opowieść o dogorywającym w błocie sofijskich przedmieść przedsiębiorstwie cyrkowym bułgarsko-włoskiej rodziny Bałkanskich staje się egzemplifikacją procesów wygaszania przez reformujące się państwo wcześniej dotowanej sfery kultury popularnej, jej degradacji materialnej, moralnej a w ślad za tym - degradacji w wymiarze ludzkim. Opowieść o bułgarskim cyrku jest metonimią destrukcji, zauważalnej w wielu innych obszarach gospodarki, przemysłu i życia społecznego. Cyrk w fazie rozkładu, próbujący pielęgnować dawne dystynkcje, ale także metafora kondycji byłych Krajów Demokracji Ludowej.

Tom zamyka artykuł pt. Chtop z Bankji, swoisty raport na temat kariery politycznej Bojko Borisowa, obecnego premiera Republiki Bułgarii, a w przeszłości ochroniarza Todora Żiwkowa. Wraz z tekstem inicjującym Złote piachy tworzy on swego rodzaju klamrę. Nieżyjąca córka bułgarskiego kacyka i jego niegdysiejszy ochroniarz jako bohaterowie Siedleckiej rysują pewną trajektorię karier politycznych, wartą uwagi antropologów i psychologów polityki. Kariera zamknięta i kariera otwarta inspirują do namysłu nad regułami wyłaniania władzy politycznej w warunkach totalitaryzmu i demokracji. W obu przypadkach budzą niepokój.

We wszystkich częściach książki przejawia się talent gawędziarski Autorki, któremu towarzyszy podszyta ironią czujność historyka kultury, a zarazem poczucie odpowiedzialności antropologa oddanego obserwacji uczestniczącej i generującego wypowiedzi, które zapewne nigdy nie zaistniałyby bez inicjatywy z jego strony. Wrażenie wielogłosowości bierze się z niejednorodności stylistycznej tekstów i wielości punktów widzenia, reprezentowanych przez różnego autoramentu postaci przewijające się w poszczególnych opowieściach. Polszczyzna w odróżnieniu od języka bułgarskiego nie zna trybu nieświadka, który służy przekazywaniu informacji niesprawdzonych, o niepewnym statusie ontologicznym. Siedleckiej udało się mimo to wydobyć tak charakterystyczną dla bułgarszczyzny, a generowaną przez ten tryb, mglistość opowiadanego świata, jako rzeczywistości domniemanej, 
zanurzonej w modalności słowa, które wzajemnie się biorą w cudzysłów. Kruchość, niesolidność ludzkich narracji o przeszłości nie staje się wszakże w Złotych piachach zachętą do relatywizmu. Co prawda, może się stać żyznym gruntem, na którym plewi się kłamstwo polityczne, które lubi karmić się bezsilnością intelektualną i moralną ludzi zagubionych w sieci nieodgadnionych znaczeń. Kruchość, niesolidność ludzkich opowieści pozostaje u Siedleckiej tym aspektem ludzkiej kondycji, który domaga się współczucia dla egzystencji nieporadnej i poranionej.

Te wielogłosowe wariacje na poszczególne tematy przefiltrowane są, jak już wspominałam, przez intelekt badacza, w stosownych momentach inkrustujący wywody bohaterów i swoje bieżące obserwacje konkretnymi informacjami wyprowadzanymi raz z akademickich ksiąg, a kiedy indziej jakby wprost z bezlitosnej analizy dekonstruowanej pamięci zbiorowej. Ten zabieg pozwala osadzić bulwersujące historie na mapie bułgarskiego imaginarium narodowego, a zarazem pokazać, że jest to rzeczywistość niestabilna semantycznie. Dzięki żywej wyobraźni antropologicznej Sylwii Siedleckiej i zdobytemu przez nią doświadczeniu naukowemu (m.in. podczas pracy nad Leksykonem tradycji bułgarskiej, 2011) zostało wykorzystane w wymagający uznania sposób: zastygły w opisie akademickim układ miejsc pamięci zbiorowej został - jak kalejdoskop - puszczony w ruch. Poprzez konkret odsłonięta została dynamika procesów konstruowania, stabilizowania i petryfikacji znaczeń w przestrzeni publicznej. W rezultacie książka Złote piachy Sylwii Siedleckiej to przewodnik po z pozoru zrujnowanych, ale wciąż gotowych do rewitalizacji pamiątkach po minionej epoce komunizmu, zachowanych - jak w przypadku mauzoleum Dimitrowa - choćby w postaci pustych miejsc. Czekają one na wypełnienie nowa treścią, pośród pleniącego się wokół ludzkiego życia.

W swojej książce Jak być uczonym (2009) Michał Heller pisze:

Praca naukowa wymaga zaangażowania, dużej wiedzy, licznych umiejętności (także pozanaukowych, na przykład organizacyjnych) i wysiłków, niekiedy aż do wyniszczenia. To wyjaławia: ujednolica perspektywę, polaryzuje kąt widzenia, zamyka szersze horyzonty. Dlatego od czasu do czasu trzeba pozwolić sobie na chwilę kontemplacji (a nawet wymusić ją w sobie), i to kontemplacji przedmiotu pracy. (...) Przygotowuje ona grunt i toruje drogę do tego błysku olśnienia, o którym mówią wielcy odkrywcy (s. 48-49).

Na książkę Siedleckiej warto spojrzeć jak na świadectwo tego rodzaju kontemplacji, która weryfikuje akademickie odkrycia humanistów w konfrontacji z wielowartościową logiką samego życia, zawsze bogatszego w możliwości interpretacyjne, niż sugerowałaby to nawet najbardziej śmiała próba systematyzacji. 